\title{
Et nordslesvigsk borgmestersamarbejde 1947-70
}

\author{
af Erik Haugbolle og Erik Jessen
}

I årene fra 1947 og frem til den store kommunalreform i 1970 udviklede der sig et nært samarbejde mellem borgmestrene i de sønderjyske købstæder. I fællesmøder drøftedes tidens vigtige spørgsmål. To af aktørerne, fhv. kommunaldirektør Erik Haugbølle og tidl. borgmester og amtsborgmester Erik Jessen, begge fra Aabenraa, fortæller her om borgmestermøderne og om mange af de større sager, som blev drøftet og gennemført i landsdelen gennem omtrent 25 år.

\section{Før 1947}

Genforeningen i 1920 betød, at de nordslesvigske købstæder, der i tysk tid havde hørt til amterne, blev udskilt fra disse, som i det øvrige Danmark. De stod således direkte under Indenrigsministeriets tilsyn i modsætning til de andre kommuner, der stod under tilsyn af de lokale amtsråd, hvor den kongevalgte amtmand var formand.

Denne særlige købstadsstatus skabte et vist fællesskab, og det var naturligt, at de fire købstæder, Haderslev, Sønderborg, Tønder og Aabenraa, søgte kontakt med hinanden for at udveksle erfaringer og synspunkter eller støtte hinanden i fælles anliggender. Et mere formaliseret samarbejde blev der dog ikke tale om i tyverne og trediverne. Det kan skyldes, at et større behov for samvirke ikke var til stede, men måske også, at Tønders borgmester indtil 1937 var tysksindet, og at borgmester Johann Jacobsen, Sønderborg, der var borgmester fra 1922 til 1933 hørte til den tysksindede fløj i Socialdemokratiet.

Først efter 1945 kom samarbejdet ind i mere faste rammer, men allerede kort tid efter Genforeningen blev de første kontakter etableret. Både i 1920 og i 1921 blev der afholdt nogle fællesmøder, hvori de fire købstæders magistrater (økonomiudvalg) deltog. Drøftelserne gjaldt løn-, pensions- og ansættelsesforhold for de kommunalt ansatte. De skulle nu tilpasses danske forhold. Andre emner kom dog også til drøftelse, og det førte til, at der senere på året i 1921 blev afholdt endnu et møde. Dette møde havde et videre perspektiv, idet også de fire amtmænd, nogle sønderjyske rigsdagsmedlemmer samt repræsentanter for handel og håndværk deltog. Emnerne var de sønderjyske garnisoners fremtidige forhold og placering samt den kommende struktur for rets- og fængselsvæsen. Man drøftede også trafikforhold og muligheden for at opnå statstilskud til en tiltrængt modernisering af de nordslesvigske havne. 


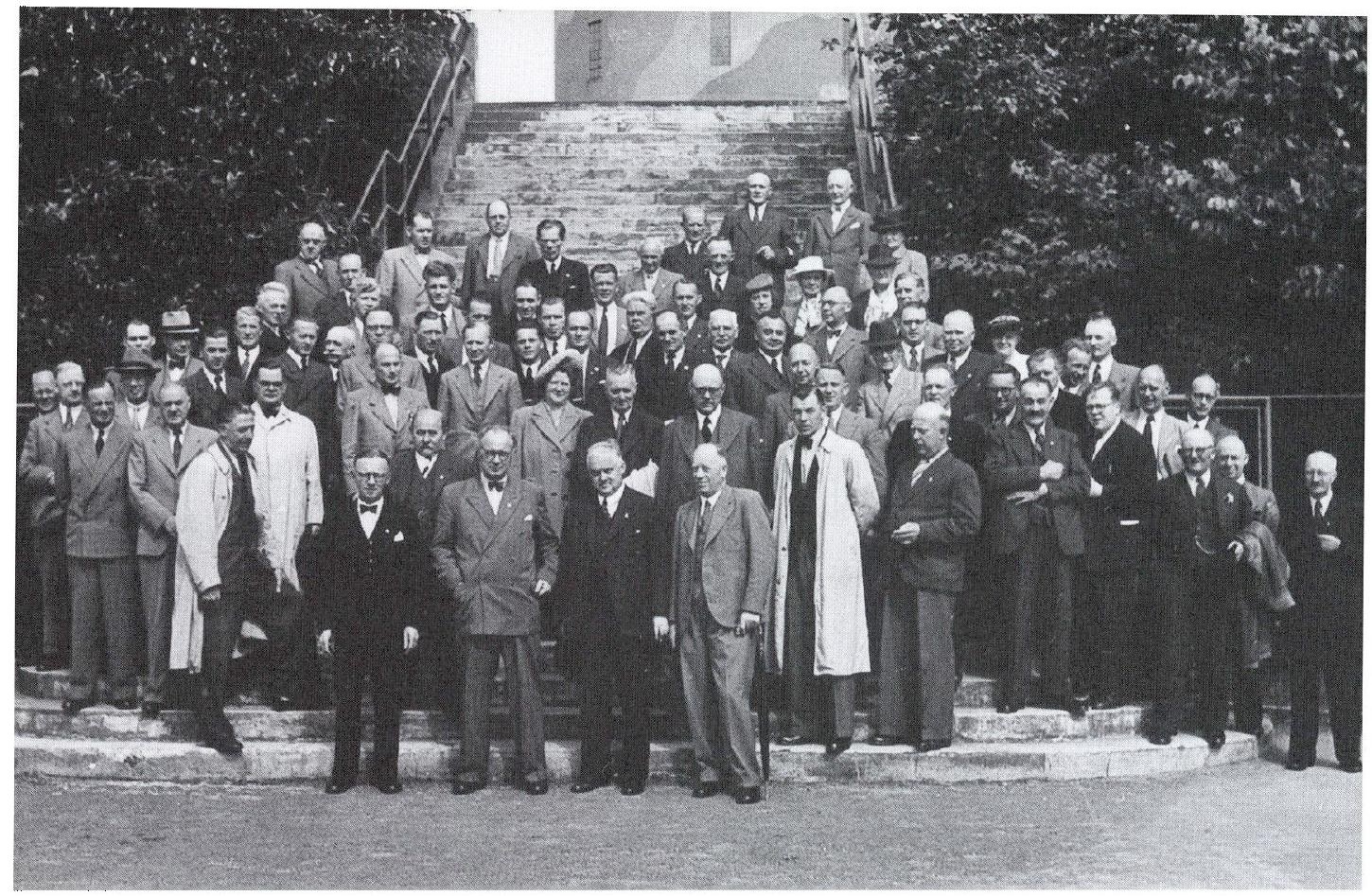

Ved de fire byråds besog $i$ Sonderborg $i 1946$ ses deltagerne her fotograferet foran vandtårnet. I forste rakke ses de fire borgmestre, fra venstre Anders Andersen, Georg Buchreitz, Johan Paulsen og Orla Christensen. Foto: O. Gronning. Institut for sonderjysk Lokalhistorie.

Den store opgave, der forestod for stat, amter og kommuner, var på det tidspunkt hurtigst muligt at bringe det genforenede Nordslesvig op på samme stade som det, der var gxldende nord for Kongeåen. Uanset behovet for en løsning af de presserende opgaver er der tilsyneladende gået flere år, inden der igen blev holdt et fællesmøde. Først $\mathrm{i}$ juli 1925 blev der på initiativ af borgmester Holger Fink afholdt et møde på Aabenraa Rådhus. I dette fælles magistratsmøde drøftedes personalesager, behandling af indfødsretssager samt boligproblemer. Antallet af indfødsretssager har givetvis været ret så omfattende. Ligeledes var bolignøden stor og vanskelig at løse så kort tid efter de fire hårde krigsår. Der har nok i høj grad været tale om erfaringsudveksling.

Allerede et halvt år senere mødtes de fire magistrater igen på Aabenraa Rådhus. Denne gang på initiativ af borgmester Johann Jacobsen, Sønderborg, som ønskede en drøftelse af købstædernes administrationsomkostninger. I Sønderborg havde man konstateret, at disse udgifter var væsentligt højere i Nordslesvigs end i Kongerigets købstæder. Som et eksempel fremlagdes en sammenligning med Svendborg. Man havde også konstateret, at udgifterne til aldersrente var højere pr. indbygger. Til imødegåelse af disse problemer blev 
det besluttet at undersøge, om der var mulighed for et højere statstilskud, og om der kunne opkræves ejendomsskat af statsejendomme.

I januar 1930 afholdtes et nyt fællesmøde. Denne gang dog alene med de fire borgmestre. ${ }^{1}$ Der foreligger intet om mødets drøftelser, men det må antages, at det igen var økonomiske problemer, der var på dagsordenen. Den verdensomspændende krise påvirkede også forholdene i Danmark. I december 1932 blev samtlige byrådsmedlemmer fra de fire købstæder indbudt til et fællesmøde i Tønder. Baggrunden herfor var den stigende arbejdsløshed, og på mødet drøftede man mulighederne for at iværksætte yderligere beskæftigelsesforanstaltninger.

Midt i den mørke besættelsestid, i juli 1942, besluttede Tønder byråd at aflægge et besøg i Aabenraa. Ideen fik tilslutning fra Sønderborg byråd, medens der ikke foreligger oplysning om, hvorvidt Haderslev har været spurgt. Formålet med Aabenraa-besøget var en besigtelse af Sønderjyllands Højspændingsværk på Aabenraa Havn. Her var situationen midt under krigen ekstraordinær, idet værket helt overvejende blev drevet af brunkul fra de midtjyske brunkulslejer. Selskabet aflagde også et besøg på rådhuset for at orientere sig om administrationens organisation og tilrettelæggelse.

Efter krigens afslutning, i august 1946, indbød Sønderborg byråd de tre øvrige byråd til et lignende arrangement. Deltagerne besigtigede et nyt vandtårn, byens elværk, alderdomshjem og ældreboliger. Besigtelsen omfattede også en ny kirkegård og en del af de nye boligbyggerier, opført af almennyttige boligselskaber. Utvivlsomt har byrådsmedlemmerne fra Sønderborg med glæde fremvist de mange nye tiltag. Byen og egnen stod netop i begyndelsen af den store opgangsperiode, som Danfoss-koncernens eksplosive vækst medførte.

De her næunte kontakter er dem, der findes »papir« på. Derudover har der sikkert ret jæunligt været telefoniske kontakter om aktuelle spørgsmål og problemer, ikke mindst $\mathrm{i}$ besættelsesårene.

\section{Fra 1947 til 1970}

Som det fremgår af foranstående, var kontakterne mellem de fire købstæder i de første 26 år efter Genforeningen ret tilfældige og uden fast mønster. Dette forhold ændrede sig efter besættelsens ophør. I oktober 1947 mødtes de fire borgmestre i Tønder, og dette blev det første af de i alt 35 borgmestermøder, som blev gennemført i perioden frem til 1970. Det må antages, at det er borgmester Johan Paulsen, Tønder, der har taget initiativ til at få gennemført disse regelmæssige møder, hvori også deltog de fire kommunaldirektører. ${ }^{2}$ 
Af mødereferatet fra det møde, der blev afholdt i oktober 1947, fremgår det, at følgende deltog: Borgmestrene Johan Paulsen, Tønder, Orla Christensen, Haderslev, Anders Andersen, Sønderborg og Georg Buchreitz, Aabenraa samt kommunaldirektørerne Edmund Melander, Haderslev, Georg Kæstel, Sønderborg, Ludvig Nielsen, Tønder og Jørgen Christensen, Aabenraa. Allerede efter de første tre møder følte man åbenbart, at samarbejdet skulle være af fast og varig karakter. Det blev besluttet at registrere de drøftede sagsområder $\mathrm{i}$ en beslutningsprotokol. Udover selve beslutningerne blev der ikke optaget referat af de synspunkter, der har været fremme på møderne. I de første elleve år efter starten af de regelmæssige møder i 1947 blev der $\mathrm{i}$ snit afholdt et møde årligt. Der var ikke fastlagt nogen mødeplàn, og møderne fandt sted efter behov.

Fra 1958 blev det til to møder hvert år. Ret ofte blev møderne udvidet til at omfatte en forhandling med de tre amtmænd. ${ }^{3}$ Ikke mindst de store fællesopgaver, der kom på bordet i 1960'erne forudsatte, at der blev givet tilslutning fra såvel amtsråd som fra de fire byråd. Og da amtmændene indtil kommunalreformens gennemførelse i 1970 var formænd for amtsrådene, kunne de ved disse møder repræsentere de enkelte amtsråd.

Fra 1965 fik forhandlingerne med amtmændene en mere fast karakter, idet hverandet møde blev et fælles amtmands- og borgmestermøde. På borgmestermøderne blev der ikke truffet endelige beslutninger, men alene afgivet indstilling til de enkelte byråd og udvalg. Det var dog yderst sjældent, at en indstilling ikke blev fulgt.

\section{Personkredsen}

Som det ses af det foregående, blev opgaverne særligt omfattende og samarbejdet mere intenst $\mathrm{i}$ årene fra 1958 til 1970. Under hensyn hertil vil det være naturligt at se lidt nærmere på de personer, der var med i den periode.

Borgmestrene var Peter Olesen, Haderslev, Anders Andersen, Sønderborg, Johan Paulsen, Tønder og Erik Jessen, Aabenraa.

Kommunaldirektørerne, ${ }^{2}$ der bl.a. havde til opgave at udforme det forberedende materiale, og som i øvrigt var ligestillede samtalepartnere på borgmestermøderne, var i den største del af perioden Georg Kæstel, Sønderborg, Ludvig Nielsen, Tønder, Tage Madsen, Haderslev (fra 1961) og Erik Haugbølle, Aabenraa (fra 1962). De tre amtmænd, der deltog i borgmestermøderne ved drøftelserne af de større landsdelsdækkende opgaver, var Jens Pinholt, Haderslev, Tyge Haarløv, Tønder og Cai Vagn-Hansen, Aabenraa og Sønderborg. 
måder en samlende person $\mathrm{i}$ det sønderjyske. Han var meget aktiv $\mathrm{i}$ ledelsen af Sønderjyllands Erhvervsråd, Sønderjyllands Højspændingsværk, Plantningsselskabet Sønderjylland og i den konservative amtsorganisation. Helt fra 1947 overtog Johan Paulsen ledelsen af borgmestermøderne. Han var den, der havde siddet længst $\mathrm{i}$ borgmesterstolen og - som på så mange andre områder virkede han som den naturlige igangsætter og koordinator.

Peter Olesen fødtes i et børnerigt, vestslesvigsk landarbejderhjem. Som ung kom han slemt til skade med det ene ben, et handicap, der siden blev ham til noget besvær. Han søgte »kontorvejen « og sluttede som stiftsbogholder ved Haderslev Stift. Peter Olesen var aktiv i HK og blev i 1933 indvalgt i Haderslev Byråd. Hans besindige gemyt og klare tanke førte til, at han i 1954 blev Haderslevs første socialdemokratiske borgmester.

Anders Andersen var skomagersøn fra Middelfart. Han blev maskinarbejder, men uddannede sig som stereotypør under sin ansættelse ved det socialdemokratiske dagblad »Sønderjyden« i Sønderborg. Efter højskoleophold og et aktivt arbejde inden for fagbevægelsen blev han i 1930 indvalgt i Sønderborg byråd, hvor han i 1946 afløste venstremanden, bankdirektør Hans Nielsen, som borgmester. En post, som han på dygtig og inspirerende vis bestred $\mathrm{i}$ næsten 25 år. Nogle få år, i alt væsentligt under besættelsen, var Anders Andersen medlem af folketinget.

Erik Jessen var 18-19 år yngre end de tre andre - stort set jævnaldrende borgmestre. Han var manufakturhandlersøn fra Aabenraa og selv manufakturhandler $\mathrm{i}$ byen. Gennem aktiv deltagelse i byens liv, bl.a. i spejderbevægelsen, blev han i 1956 medlem af Aabenraa Byråd, hvor han repræsenterede Dansk Liste uden for Partierne. Ved valget i 1958 blev han valgt på en fallesliste, bestående af Dansk Liste uden for Partierne, Venstre og Det Radikale Venstre. Efterfølgende blev Erik Jessen valgt til borgmester.

Som rådgivere - enten for hele kredsen eller for den enkelte borgmester - gled kommunaldirektorerne naturligt ind i borgmestersamarbejdet, og de fik i flere sager stor betydning for resultatet af de førte drøftelser. Men i sagens natur måtte det være politikerne, altså borgmestrene, der udadtil tog ansvaret for de trufne beslutninger. Samarbejdet kommunaldirektørerne imellem var præget af den løbende kontakt, der ikke mindst i 1960'erne fandt sted mellem dem. De kendte hinanden godt fra deres kollegaforening - Kæmnerforeningen - og endvidere havde Tage Madsen og Erik Haugbølle allerede før flytningen til Sønderjylland haft et nært samarbejde i Frederiksborg Amt. 
administration, i første omgang med titel af kontorchef, der i 1963 blev ændret til kommunaldirektør.

Tage Madsen startede sin kommunale løbebane i Taarnby, hvor faderen var stationsforstander ved Amagerbanens rutebilsektion.

Allerede som 25-årig blev Tage Madsen leder af den kommunale administration i Farum kommune i Nordsjælland. Denne stilling bestred han i næsten 20 år, indtil han i 1961 begyndte som kommunaldirektør i Haderslev.

Erik Haugbolle var proprietærsøn fra Fyn. Det var også her, han efter endt skolegang startede som elev på kommunekontoret i Vissenbjerg. Efter ansættelse i kommuner på Fyn og Sjælland, senest som administrationschef i Hundested kommune, blev han i 1962 ansat som kommunaldirektør i Aabenraa kommune.

De fire amtsråd dækkede alene landkommunerne, mens købstæderne, som nævnt, havde deres egen selvstændige status. I de tilfælde, hvor det drejede sig om opgaver, der var fælles for hele landsdelen, var det derfor naturligt og nødvendigt tidligt at inddrage amtmandene, der også var formænd for amtsrådene, i drøftelserne. Det førte $\mathrm{i}$ årenes løb til et mere og mere snævert samarbejde. I de såkaldte »udvidede borgmestermøder « (amtmænd og borgmestre) ydede de tre amtmænd meget positive bidrag til løsning af de store opgaver.

De var dygtige administratorer $i$ hver deres amt og samtidig rutinerede formænd for deres amtsråd, hvis medlemmer de holdt nær kontakt med. Som formænd for store dele af det sønderjyske sygehusvæsen fik de afgørende indflydelse på dette områdes udvikling, og de virkede $\mathrm{i}$ det hele til fremme af sønderjyske tiltag og interesser.

Jens Pinholt, der var klitplantørsøn fra Vejers, blev efter en årrække i Indenrigsministeriet, senest som kontorchef, udnævnt til stiftamtmand i Haderslev midt under de mørke besættelsesår.

Tyge Haarløv, der havde oplevet nogle af sine drengeår i Haderslev, hvor faderen blev stiftamtmand i 1920, blev, efter en karriere i Socialministeriet og Arbejdsministeriet med slutstilling som departementschef, i 1960 udnæunt til amtmand i Tønder.

Cai Vagn-Hansen, der var født og opvokset i hjemmet hos kabinetssekretær C.P.M.Hansen i København, blev udnævnt til amtmand over Aabenraa og 
Sønderborg amter i 1954. Inden da havde han i en årrække været amtmand, senere rigsombudsmand, på Færøerne.

\section{Emner og opgaver}

Ser vi ned over rækken af de mange sager, der har været til drøftelse i de mere end tredive møder, fremgår det tydeligt, at langt de fleste drejede sig om ansøgninger om støtte til forskellige formål. Her var det for de fire købstæder af vigtighed at finde frem til ensartede holdninger. Af hensyn til overskueligheden er der foretaget en opdeling af emneområderne.

\section{Tilskud til opgaver uden for landsdelen}

I stort omfang tog borgmestrene afstand fra at yde ensartede tilskud til opgaver uden for landsdelen. Kendetegnende for disse afslag var, at formålene ikke havde direkte betydning for Nordslesvig, men der blev dog også vist imødekommenhed i enkelte sager. Eksempelvis over for en ansøgning om støtte til et studenterhus i Århus, da mange unge fra Sønderjylland læste ved Århus Universitet. Også et børnehjem i Grønland, et monument i koncentrationslejren Neuengamme samt Klokkestablen på Skamling mødte velvilje. Af andre anbefalinger er der grund til at nævne købstædernes støtte til Kronprinsesse Ingrids Feriehjem for Sønderjyske Børn.

På borgmestermøderne blev der løbende truffet aftale om fælles retningslinier i forhold til de mange ansøgninger, som købstæderne modtog fra landsdækkende foreninger med humanitære, sygdomsbekæmpende og kulturelle formål.

\section{Opgaver inden for landsdelen}

Ganske mange af de projekter, der i perioden fra 1947 til 1970 er gennemført i landsdelen, har nydt godt af det nære samarbejde mellem købstadkommunerne. Det gælder f.eks. Refugiet i Løgumkloster. Omend der måtte flere drøftelser til, inden man nåede frem til en positiv holdning, så endte sagen dog med, at borgmestrene anbefalede, at købstæderne ydede tilskud til opførelse af denne bygning. Anbefalet blev også Den Nordslesvigske Kvindeforenings Rekreationshjem på Rømø, hvortil der blev ydet støtte i flere omgange. Også Brandværnsmuseet i Christiansfeld blev anbefalet.

Man var enige om, at kollegiebyggeri i de nordslesvigske købstæder måtte betragtes som en lokal opgave. Denne retningslinie blev fastlagt, da Komiteen til rejsning af et 4. Maj Kollegium i Aabenraa søgte om et etableringstilskud. En tilsvarende holdning indtog man til opføreisen af Idrætshøjskolen i Sønder- 
borg og til flytningen af Mutter Stallboms hus fra Aabenraa til Købstadmuseet i Århus. Der var også afslag til en ansøgning om tilskud til renoveringen af Kommandørgården på Rømø. Ejendommen ejedes af Nationalmuseet, og blev derfor betragtet som en statsopgave. Til gengæld var man enige om, at der $\mathrm{i}$ et vist omfang kunne ydes tilskud til nyanskaffelser til Specialarbejderskolen i Aabenraa (nu AMU-center).

Enkelte gange kunne det ske, at samarbejdet ikke omfattede alle fire købstæder. Det var tilfældet, da Haderslev, Tønder og Aabenraa besluttede at yde økonomisk støtte til opførelse af lufthavnsterminalbygningen i Skrydstrup (nu Vojens) Lufthavn.

Alle borgmestre gik ind for at anbefale tilskud til bogudgivelser om Grænsegendarmeriet og de Nordslesvigske statsskolers første halvtreds år, samt til Historisk Samfund for Sønderjylland. I en længere årrække ydede de fire købstæder mindre tilskud til den årlige §̊-udstilling i Aabenraa. Til disse kunstudstillinger, der var resultatet af et samarbejde mellem de tre Å-byer, Aalborg, Århus og Aabenraa, ydede Aabenraa som udstillingsby meget naturligt et ekstraordinært tilskud. Spørgsmålet om en videreførelse af tilskud til udstillingen blev taget op til drøftelse i 1963. Efter nogen diskussion blev det besluttet at fortsætte disse tilskud, dog med henstilling om »at vise mere forståelig kunst «. Det var et vanskeligt ønske at opfylde, idet $\AA$-udstillingens formål var at vise ny og ung, dansk kunst. Det kan i dag vække til eftertanke, at de kunstnere, der gav anledning til borgmestrenes kommentar, bl.a. var Vibeke Alfeldt, Jørgen Brynjolf, Per Nyborg, Ole Schwalbe, Lagoni Jacobsen, Jan Leth og Børge Jørgensen.

\section{Samordning af administrative retningslinier}

Et område, der hyppigt blev drøftet i borgmesterkredsen, var forhold omkring den kommunale administration. Som næunt var det netop personaleforhold, der var anledning til afholdelse af det første fællesmøde. Ofte havde disse drøftelser karakter af erfarings- og meningsudvekslinger, men af og til blev det besluttet at afstikke visse retningslinier. Det skete eksempelvis med hensyn til fastlæggelse af regler om telefon- og rejsegodtgørelser, såvel for personale som for byrådsmedlemmer. Det gjaldt også ved fastsættelse af betingelserne for eventuel deltagelse i Dansk Kommunalkursus og for oprykning fra assistent til overassistent.

Også kommunernes økonomi var løbende til debat. Det kunne være spørgsmålet om indførelse af dækningsafgift på erhvervsejendomme, tilskud til lokalt ungdomsarbejde, ophævelse af huslejestop, optagelse af lån og fastsættelse af beskatningsprocenter. Af andre tiltag kan nævnes, at oberst C. G. Bartholdy i 1949 deltog i mødet for at orientere kredsen om hjemmeværnets opbygning og organisation. I 1951 blev der truffet beslutning om at annoncere i det tyske 


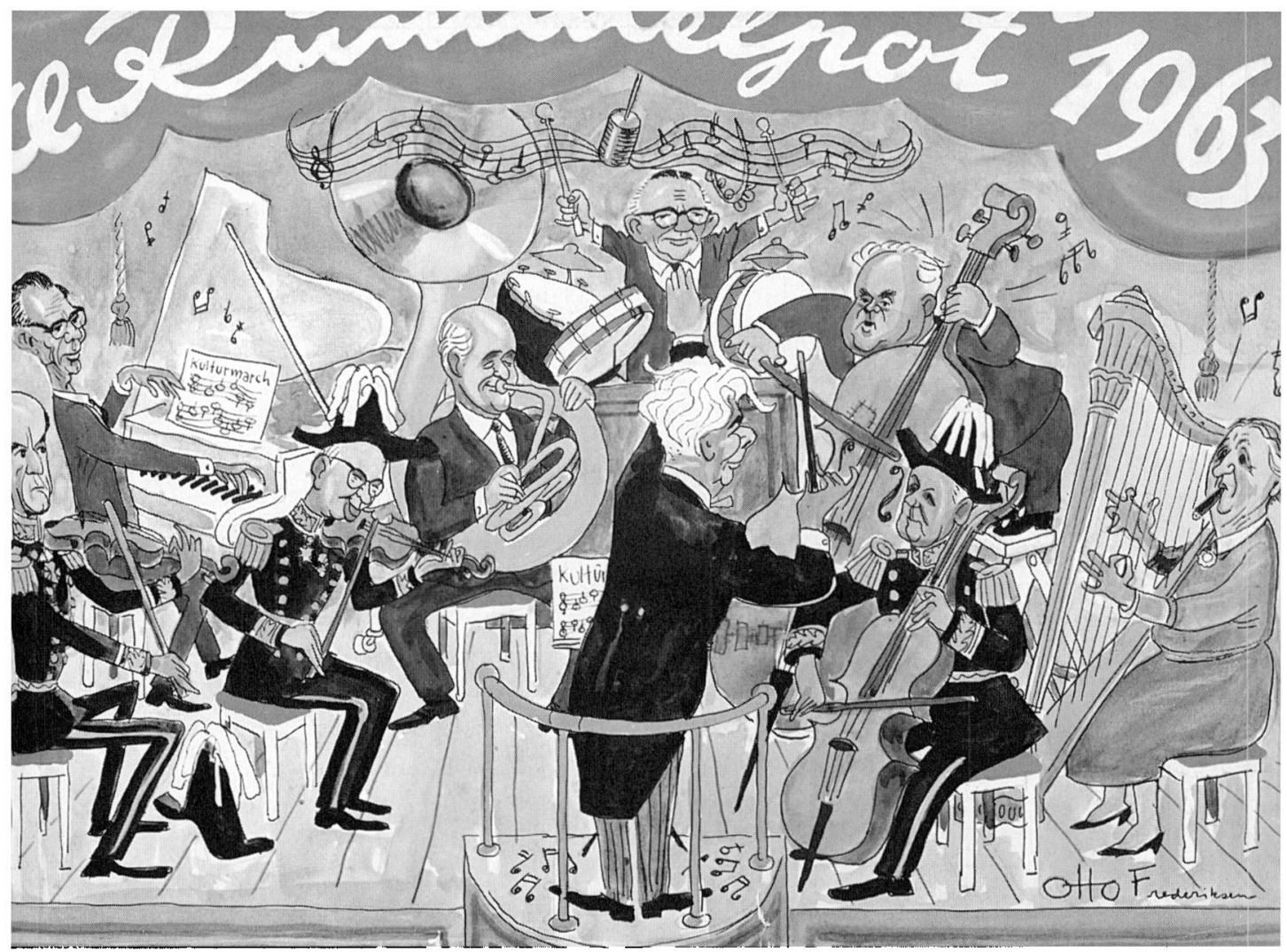

Amtmand og borgmestre undgik ikke mat komme i A Rummelpot". Her ses de i 1963 sammen med Ingeborg Refslund Thomsen under direktion af kulturminister Julius Bomholt. Opstillingen er inspireret af Sonderjyllands Symfoniorkesters start. Fra venstre ses Tyge Haarlov (violin), Peter Olesen (fygel). Cai Vagn-Hansen (violin), Erik Jessen (tuba), Anders Andersen (slagtoj), Johan Paulsen (kontrabas), Jens Pinholt (cello) og Ingeborg Refslund Thomsen (harpe). På dirigentpodiet Julius Bomholt. Tegning: Otto Frederiksen.

mindretals avis, Der Nordschleswiger, som på dette tidspunkt begyndte at udkomme som dagblad.

I 1952 var der enighed om, at tiden endnu ikke var inde til at lukke de offentlige kontorer om lørdagen. Det blev samme år tilkendegivet, at købstæderne burde anskaffe $\mathrm{FN}$-flag til flagning på FN-dagen og ved andre passende lejligheder. Endvidere blev det besluttet, at man ville tilstræbe en begrænsning af de nordiske venskabsby-besøg, som åbenbart havde taget et vel stort omfang.

\section{De store landsdelsdakkende opgaver}

Som det fremgår af foranstående, har borgmestermøderne været et forum, hvor der blev taget stilling til mange af de daglige problemer, som året igennem dukkede op på borgmestrenes og kommunaldirektørernes skriveborde. Selvom mange af de rejste spørgsmål hørte under »småtingsafdelingen«, var det både 
praktisk og af en vis betydning, at købstæderne kunne fremtræde med en ensartet holdning. Dog er det nok af mere almen interesse at følge det samarbejde, der i disse år fandt sted omkring de store sønderjyske opgaver. Mange af disse sager havde en vidtrækkende karakter, og i de tilfælde blev spørgsmålene ikke alene gjort til genstand for en eller flere drøftelser i borgmesterkredsen, men efterfølgende også i et fællesmøde med de sønderjyske amtmænd.

I 1950 anmodede borgmester Georg Buchreitz, Aabenraa, om at man drøftede en ansøgning fra »Udvalget til Fremme af Erhvervsmulighederne i Sønderjylland « om driftstilskud til oprettelse af et sekretariat. Erhvervsudvalget, der havde eksisteret siden 1947, bestod af folketings- og landstingsmedlemmer og nogle få amtsrådsmedlemmer. Initiativtager og formand var direktør Jes Christiansen, Sønderjyllands Højspændingsværk. I 1950 var arbejdet blevet så omfattende, at det var påkrævet, at der blev oprettet et egentligt sekretariat. Erhvervsudvalget opfordrede derfor de fire købstæder til at medvirke med årlige driftstilskud.

Borgmestrene udtalte, at »de var villige til at anbefale de respektive byråd at støtte et sådant sekretariat, såfremt erhvervsudvalget blev organiseret på et fast og mere officielt grundlag og med tilsagn fra stat og amtskommuner om tilskud til drift og arbejde«. Man fandt det altså rimeligt, at både stat $o g$ amtskommuner blev inddraget i finansieringen, og at disse samtidig sikredes indflydelse gennem repræsentation i de styrende organer. Jes Christiansen slog straks til. Han fik gennemført de fornødne forhandlinger, og det siden så kendte organ Sonderjyllands Erhvervsråd var en realitet, såvel økonomisk som med en bred ledelsesstruktur, hvor Egnsudviklingsrådet, amtsråd og byråd samt erhvervs- og fagorganisationer var repræsenteret. I de første mange år blev rådets daglige virke varetaget af erhvervsrådssekretær, cand. oecon. Peter Groth Bruhn, og ikke mindst hans indsats var medvirkende til, at rådet blev en vigtig faktor $i$ landsdelens erhvervsmæssige udvikling.

I 1956 fremlagde borgmester Peter Olesen, Haderslev, et forslag om et samlet sønderjysk initiativ med henblik på at gennemføre en stærkt tiltrængt renovering af Den sonderjyske kirkegård i byen Braine $i$ Frankrig. Her var der efter den første verdenskrig indrettet en særlig kirkegård for dansksindede sønderjyder, der faldt i første verdenskrig. Resultatet af disse drøftelser blev, at Haderslev med finansiel støtte fra de øvrige købstæder skabte de fornødne kontakter og sikrede, at den nødvendige renovering blev gennemført. Herefter blev kirkegården genindviet ved en større højtidelighed. Initiativet medførte i øvrigt, at Haderslev, der som bekendt er hjemsted for Slesvigske Fodregiment, knyttede varig venskabsbyforbindelse med byen Braine.

Den sag, der oftest kom med på borgmestrenes dagsorden, var Sonderjyllands Symfoniorkester. Helt tilbage fra 1947 ansøgte det dengang private Søn- 
derjyllands Symfoniorkester i Sønderborg jævnligt om driftstilskud. Bag orkestret stod en kreds af musikinteresserede borgere på Sønderborg-egnen med direktørerne Sv.O. Hansen og K. H. Sørensen i spidsen. Orkestrets faste dirigent var organist Hakon Elmer.

Ansøgningerne blev hver gang starkt anbefalet af borgmester Anders Andersen, Sønderborg, men begejstringen hos de tre kolleger var begrænset. Man mente, at Sønderborg selv burde kunne løse denne opgave. Sønderborg sad jo i særdeles gode kår med et højt indtægtsgrundlag og med en af landets laveste beskatningsprocenter, bl.a. som følge af egnens stærke erhvervsudvikling. Helt afvisende var de tre købstæder dog ikke. Således bevilgedes i 1947 et tilskud på 20 øre pr. indbygger under forudsætning af, »at Sønderborg betalte betydeligt mere«. Nogle år senere krævede de tre borgmestre, at også amterne ydede bidrag, "f.eks. 10 øre pr. indbygger«.

Helt op til 1961 var tilskuddene meget varierende, og enkelte år faldt de bort. Bevillingen i 1961 skete under forudsætning af, at der blev etableret en mere fast ordning for orkestrets virksomhed og økonomi. Hertil blev man hjulpet af en ny lov om landsdelsorkestre uden for København. Loven åbnede mulighed for, at det normale 50\% statstilskud kunne forhøjes til $75 \%$ i områder, hvor der ikke fandtes en storby. Denne mulighed var bl.a. medtaget af hensyn til Sønderjylland.

I 1962 lykkedes det borgmestrene at formå kulturminister Julius Bomholt til at deltage i et møde på Aabenraa Rådhus. Foruden repræsentanter fra de sønderjyske amts- og byråd var der inviteret en række personer fra musikinteresserede kredse og fra andre kulturelle organisationer m.m. Endvidere deltog repræsentanter fra Sydslesvig. Gennem et meget inspirerende indlæg lykkedes det 'for kulturministeren at overbevise de sidste tvivlere om nødvendigheden af, at der nu blev oprettet et egentligt Sønderjyllands Symfoniorkester med hjemsted i Sønderborg. På mødet vakte det en vis moro, da det kendte amtsrådsmedlem, Alfred Kristensen, Bylderup, udtalte, at man måtte huske, »at vi fra Vesteregnen endnu kun var nået til harmonikastadiet«. Der blev nedsat et arbejdsudvalg, der fik amtmand Cai Vagn-Hansen som formand. Det kunne meget hurtigt fremlægge forslag til orkestrets organisation, økonomi og virksomhed. Forslaget blev efterfølgende vedtaget $i$ alle amts- og byråd, omend ikke alle steder enstemmigt. Da også de interesserede organisationer kunne tilslutte sig, og der opnåedes tilsagn om $75 \%$ statstilskud, kunne Hakon Elmer i overværelse af kong Frederik i 1963 slå taktstokken an til orkestrets første koncert i Frihedshallen i Sønderborg.

Symfoniorkestret blev hurtigt en populær og skattet institution, og det gjaldt ikke alene orkestervirksomheden. De mange velkvalificerede musikere, der blev knyttet til orkestret, har årene igennem dannet en række mindre grupper, som 
har medvirket overalt i landsdelen. Også gennem disse arrangementer, der har omfattet såvel populær som den mere avancerede musik, har orkestrets tilstedeværelse haft en overordentlig gunstig indflydelse på musiklivet i landsdelen. Stor betydning fik orkestermedlemmerne også for de kommunale musikskoler, der med Haderslev som foregangskommune ret hurtigt blev etableret i de fire købstæder. Undervisningen på disse musikskoler blev - og bliver stadig - i stort omfang varetaget af musikere fra Sønderjyllands Symfoniorkester.

I 1962 tog Peter Olesen initiativ til, at en række sønderjyske planlægningsproblemer blev drøftet i borgmesterkredsen. Baggrunden herfor var ønsket om at få igangsat en fælles planlagning for erhvervsudviklingen $i$ Sonderjylland. Peter Olesen ønskede også at få igangsat en egentlig landsdelsplanlcegning, ligesom han fandt det hensigtsmæssigt at få udarbejdet forslag til en ny kommunal inddeling, som skulle »baseres på størrelse, struktur og økonomiske muligheder«. Et fjerde forslag var et ønske om at opnå sønderjysk enighed om en fordeling af de vigtigste kulturelle institutioner.

De her rejste spørgsmål var ikke nye for borgmestre og kommunaldirektører, men det var første gang, at de i deres helhed blev drøftet i denne kreds. Efterfølgende blev Peter Olesens forslag taget op til overvejelse i flere omgange. Således blev spørgsmålet om en samlet plan for de overordnede kulturelle opgaver i Sønderjylland gjort til genstand for en fælles drøftelse med de tre amtmænd. Ved disse forhandlinger enedes man om at arbejde for:

at symfoniorkestret fortsat skulle placeres i Sønderborg,

at Tønder skulle være hjemsted for et sønderjysk kunstmuseum,

at en lærerhøjskole og et evt. kommende syd- og sønderjysk universitet skulle placeres i Haderslev, samt

at en evt. kommende landsdelsscene skulle have hjemsted i Aabenraa.

En landsomfattende debat om lands- og egnsplanlægningen var i gang på grundlag af nogle udspil fra Landsplanudvalget og andre, herunder professor Johannes Humlums mere utraditionelle forslag til en ny landsplan. Drøftelsen af Peter Olesens forslag resulterede i, at borgmestrene bad Sønderjyllands Erhvervsråd udarbejde oplæg til et erhvervsudviklingsprogram.

Forhandlinger med bl.a. handelsminister Hilmar Baunsgaard førte til, at også staten og egnsudviklingsrådet blev inddraget $\mathrm{i}$ arbejdet, og der nedsattes et større udvalg, som fik til opgave at udarbejde et udviklingsprogram for Sonderjylland. Udvalget fik 24 medlemmer, de fleste lokale. Egnsudviklingsrådets formand, direktør K. Skat Rørdam, blev formand for udvalget, medens de to næstformandsposter tilfaldt borgmester Johan Paulsen og direktør M. F. Schøler, Danfoss. I 1968 kunne udvalget fremlægge en fyldig rapport med et omfattende statistisk materiale under navnet "Sønderjyllands Udviklingsprogram" med undertitlen »Egnsudvikling under økonomisk vækst«. 


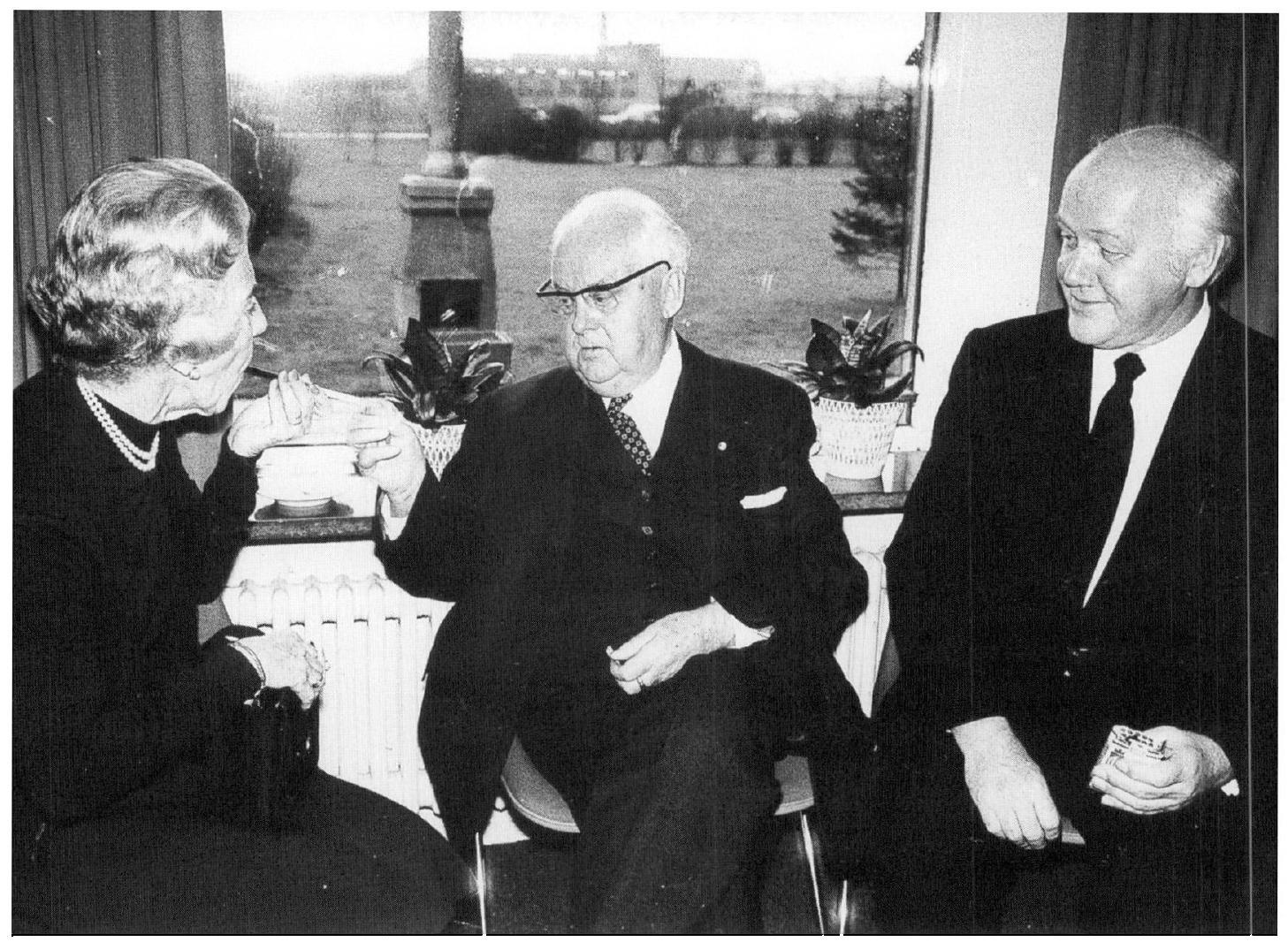

Der blev ogsả tid til mere afslappede stunder, som her, hvor Dronning Ingrid ses $i$ samtale med Johan Paulsen og Erik Jessen i en pause ved en stipendieuddeling på Tonder Tekniske Skole i 1960'erne. Foto: Privateje.

Betænkningen blev aldrig omsat til et egentligt handlingsprogram, men den blev et godt redskab i erhvervsrådets og de sønderjyske kommuners arbejde. Samtidig blev den et nyttigt instrument i den regionplanlægning, som Sønderjyllands Amtsråd gennemførte efter 1970.

Debatten om en ny kommunal struktur var så småt igang på baggrund af nogle udspil, der især berørte de ofte ret så komplicerede forhold omkring købstædernes byudviklingsproblemer.

Tanken om at få udarbejdet en fælles plan for en revision af kommunegrænserne omkring de sønderjyske købstæder måtte imidlertid opgives. De i 1960 'erne gennemførte undersøgelser og vurderinger blev tilvejebragt af de enkelte amter - uden nogen form for koordinering ud over amtsgrænserne. De ønsker, som byrådene i Haderslev, Sønderborg og Tønder havde fremført for at få rimelige udviklingsmuligheder, blev i stort omfang tilgodeset, da Kommunalreformkommissionen traf sin endelige afgørelse om den nye kommunale inddeling. Det blev derimod ikke tilfældet for Aabenraa's vedkommen- 
de. Kommunen måtte affinde sig med en snæver vestlig afgrænsning, der kom til at følge linien for den nye motorvej.

De store bestræbelser, som Haderslev byråd og Haderslev amtsråd udfoldede for at sikre Haderslev et universitetscenter blev resultatløse. Man var her oppe imod stærke kræfter. Eksempelvis havde Landsplanudvalget flere gange »udnævnt« Esbjerg til landsdelscenter for det sydlige Jylland og Sønderjylland. Hertil kom, at indflydelsesrige sønderjyder og sønderjysk-interesserede arbejdede for en placering uden for Sønderjylland. Det var grænsepolitiske synspunkter, der dikterede denne holdning, og det var med til at vanskeliggøre arbejdet for at få placeret et universitetscenter i Haderslev. Heller ikke de gamle nationale foreninger var positive. I det hele taget var der i vide kredse en vis usikkerhed $i$ vurderingen af fordele og ulemper ved at huse et universitetscenter i Sønderjylland og i den i forhold til andre universitetsbyer dog ret lille Haderslev by.

Disse forhold prægede også debatten i amtmands- og borgmesterkredsen, hvor f.eks. Sønderborg en overgang luftede tanken om en placering på Augustenborg Slot. Men i efteråret 1964 mødtes amtmænd og borgmestre på Aabenraa Rådhus og gav fuld støtte til Haderslevegnens universitetsplaner. Amtmænd og borgmestre deltog også positivt $\mathrm{i}$ de efterfølgende forhandlinger på politisk plan både i Haderslev og i København, men slutresultatet blev, at Folketinget traf beslutning om, at et evt. sjette universitetscenter skulle placeres i Ribe-Esbjerg området. Om dette nogensinde sker, er endnu i dag svært at vurdere.

Planerne om at etablere en sønderiysk landsdelsscene i Aabenraa fik en helt anden afslutning end sagen om Sønderjyllands Symfoniorkester. I 1962 fik Sønderjysk Teaterforening, og andre teaterinteresserede kredse, nedsat en sønderjysk teaterkommission med amtsrevisor Hans Christensen, Tønder, som formand. Kommissionen nedsatte igen et arbejdsudvalg ledet af amtskontorchef Jes P. Caspersen, Aabenraa.

Samarbejdet om teatervirksomhed var ikke noget nyt. Gennem årene havde borgmestrene jævnligt anbefalet byrådene at yde tilskud til Sønderjysk Teaterforening. Dette forhold blev taget op til nyvurdering i 1964. På et borgmestermøde blev det besluttet at henstille til teaterforeningen at finde frem til en mere fast økonomisk ordning, hvor borgmestrenes forudsætninger var, at også andre ydede bidrag til teatervirksomheden. Her tankte man især på staten og de sønderjyske amtskommuner. I forbindelse hermed blev der peget på nødvendigheden af, at der skabtes grundlag for en gennemgribende forbedring og modernisering af de eksisterende teaterscener.

Arbejdet i den sønderjyske teaterkommission resulterede i, at kulturminister Julius Bomholt gik ind i sagen. Han fik i 1964 nedsat en kommission, der 


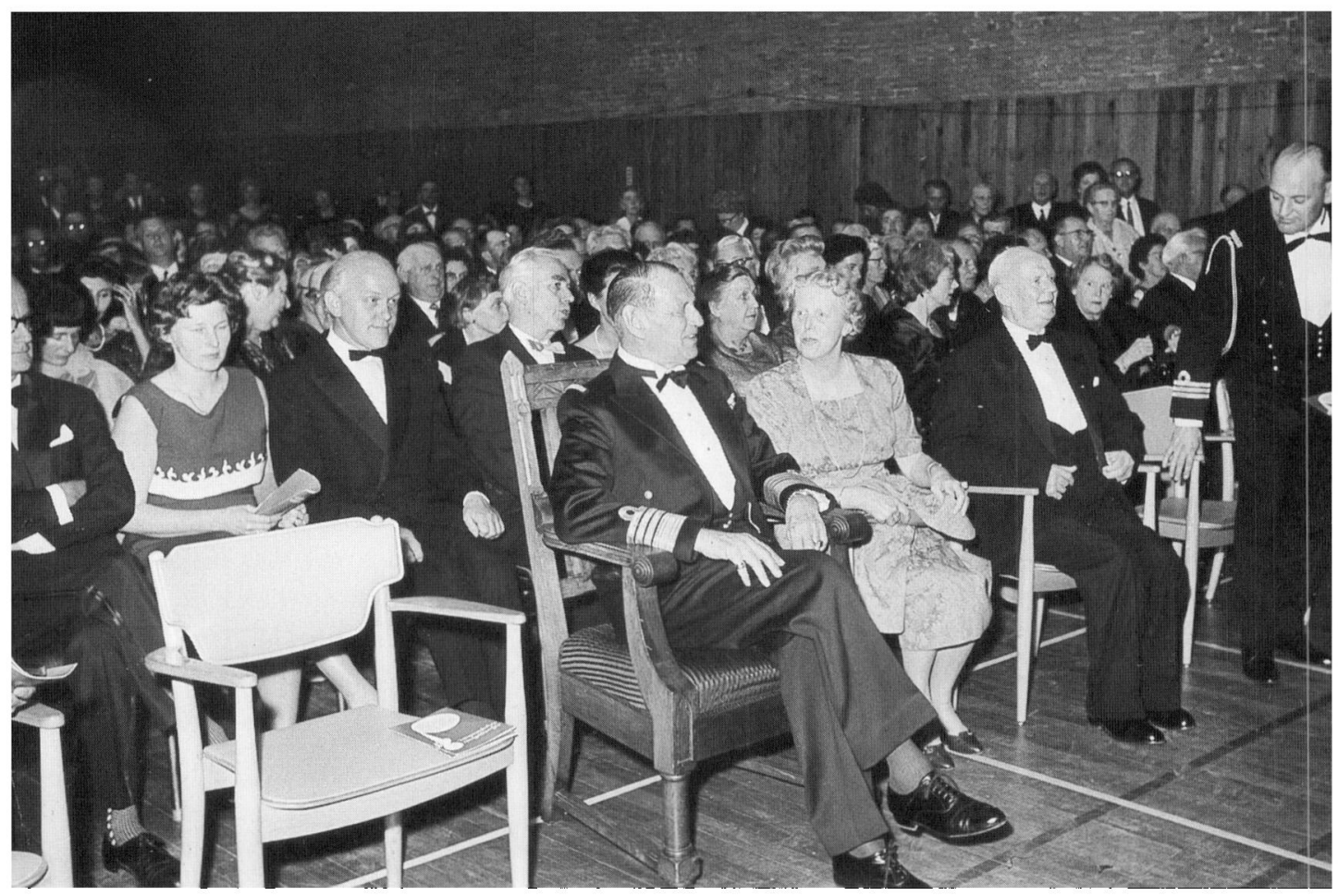

Ved Sonderjyllands Symfoniorkesters åbningskoncert ses her fra venstre Tyge Haarlov, Lissen Jessen, Erik Jessen, generalkonsul Troels Fink, Flensborg, kong Frederik, Ingeborg Refslund Thomsen (anden rakke), bispinde Beyer og biskop Frode Beyer. Foto: Weber. Privateje.

skulle udarbejde forslag til oprettelse af en landsdelsscene i Sønderjylland. Ekspeditionssekretær J. Harder Rasmussen, Kulturministeriet, blev udpeget til formand for kommissionen. Endvidere indtrådte - foruden repræsentanter for Sønderjysk Teaterforening m.fl. - amtmand Tyge Haarløv, Tønder, og borgmester Erik Jessen, Aabenraa.

Betænkningen forelå i 1968, og samme år blev den drøftet $\mathrm{i}$ et amtmandsog borgmestermøde samt efterfølgende i de sønderjyske amtsråd og byråd. Sagen gav også anledning til, at der blev udarbejdet et løst skitseprojekt, som viste mulighederne for at placere en teaterbygning ved Sønderjyllandshallen i Aabenraa.

På dette tidspunkt stod den store kommunalreform imidlertid for døren, og alle var derfor enige om, at teatersagen burde oversendes til det nye Sønderjyllands Amtsråd, som skulle påbegynde sin virksomhed den 1.april 1970. Efter forudgående drøftelser i amtsrådets undervisnings- og kulturudvalg, i økonomiudvalget samt $i$ de politiske grupper fremsatte den socialdemokratiske amtsrådsgruppe et forslag om, at Sønderjyllands Amtsråd skulle arbejde videre med planen med henblik på at få gennemfort en etapevis opbygning af en 
landsdelsscene i Aabenraa. Ved afstemningen i amtsrådet blev forslaget forkastet, idet Venstre, Konservative, Slesvigsk Parti og den radikale Svend Ingomar Petersen stemte imod. Også den nyvalgte amtsborgmester Erik Jessen, der ellers meget positivt havde deltaget i det forberedende arbejde, gik imod. Han fandt det ikke forsvarligt at gennemføre et så kompliceret projekt med en enkelt stemmes flertal. Ligesom han anså det for urealistisk at forsøge gennemført en etapevis opbygning. Herefter blev sagen henlagt, og den er ikke siden blevet genoptaget.

En medvirkende årsag til amtsrådets negative holdning har sandsynligvis været, at der - efter kommunalreformen - kun var een lokal tilskudsgiver, nemlig Sønderjyllands amtskommune. Tidligere ville det have været de fire amter og de fire købstæder, og på den måde ville de enkelte bevillinger have virket mindre belastende.

Måske lå der også lidt geografisk politik i afgørelsen. Mange var af den opfattelse, at Aabenraa, der var blevet center for den nye amtskommunale administration, havde fået rigeligt af fordele.

En drøftelse af spørgsmålet om udbygning og modernisering af kobstadbibliotekerne endte med enighed om, at dette alene var en kommunal opgave. Aabenraa regnede dog med at kunne opnå et særligt statstilskud til et nybyggeri, da det tyske mindretal netop havde opført et helt nyt centralbibliotek i Aabenraa. Et sådant statstilskud blev ikke opnået, men alle fire købstæder gennemførte i disse år omfattende nybyggerier, moderniseringer og udvidelser af bibliotekerne. Biblioteket i Aabenraa blev - takket være et intenst arbejde fra tidligere borgmester Georg Buchreitz's side - udpeget til centralbibliotek for landsdelen.

I 1965 orienterede Erik Jessen borgmesterkredsen om, at Aabenraa kommune lå i forhandling med undervisningsministeriet om etablering af et landsdelsdækkende undervisningscenter for svert handicappede born. Sammen med undervisningsinspektør J. Skov Jørgensen var der tilvejebragt et skitsegrundlag for et sådant center, der i første omgang skulle etableres i nogle midlertidige lokaler. Senere skulle centret flyttes til en nyopført skole, Brundlundskolen, hvor Aabenraa kommune var villig til at finansiere en tilbygning til centret. Driftsudgifterne, herunder leje af bygning samt transport af de handicappede børn, skulle fordeles efter benyttelse, og planen krævede derfor en godkendelse af såvel amter som købstæder. Amtmænd og borgmestre gav tilslutning til, at Aabenraa kunne arbejde videre med planen, der da også blev realiseret.

Efter en række forudgående forhandlinger kunne Tyge Haarløv og Erik Jessen i et amtmands- og borgmestermøde i 1965 fremlægge en plan om, at de hidtidige arbejdstekniske skoler blev centraliseret i en sonderjysk specialarbejderskole i Aabenraa (det senere AMU-center). Planen havde været længe 
undervejs, men ikke mindst $\mathrm{i}$ kraft af et positivt samarbejde med daværende arbejdsformidlingschef Frederik Hansen, Haderslev, og i kraft af, at Aabenraa kommune havde erklæret sig villig til at opføre en passende bygning og leje den ud til formålet, var der åbnet mulighed for at opnå driftstilskud fra staten. På amtmands- og borgmestermødet blev der givet tilslutning til planen, og allerede året efter kunne Specialarbejderskolen Sønderjylland indvies af arbejdsminister Tyge Dahlgaard. Skolen er gennem årene blevet udvidet flere gange, i øvrigt også med afdelinger i andre sønderjyske byer.

Selvom der i stort omfang blev givet tilslutning til de fremlagte forslag, kunne det naturligvis forekomme, at der ikke var fuld enighed blandt de fire borgmestre. Det var eksempelvis tilfældet, da Erik Jessen i 1967 foreslog, at man undersøgte muligheden for at få etableret en statslig lufthavn ved Rødekro, hvor der i forvejen fandtes en mindre landingsbane. Baggrunden for forslaget var en betænkning om fremtidige provinslufthavne, der i Sønderjylland pegede på denne mulighed. Forslaget vandt ingen genklang hos de øvrige borgmestre, og sagen blev derfor henlagt. Spørgsmålet om flytrafikken til og fra hovedstaden, herunder etablering af lufthavne i Sønderjylland, var ofte til debat, og ved disse lejligheder fremhævede borgmester Anders Andersen, Sønderborg, at det af hensyn til den store industriudvikling på Als var nødvendigt at fastholde en lufthavn i nærheden af Sønderborg.

Da det kort tid efter, af byudviklingsmæssige grunde, viste sig nødvendigt at flytte den eksisterende Sønderborg Lufthavn, fremkom de tre øvrige borgmestre gennem erhvervsrådet med et forslag om i stedet at bygge en ny sønderjysk lufthavn syd for Blans på Sundeved tæt ved den planlagte nye Alssundbro. Dette forslag, som reprasentanter for Sønderjyllands Erhvervsråd separat forhandlede med Anders Andersen og hans medarbejdere ved et møde på Sønderborg Rådhus, blev ligeledes afvist. For at tilgodese de nordlige og centrale områder i landsdelen, lykkedes det derefter for de tre borgmestre i samarbejde med lokale repræsentanter at få åbnet den militære Skrydstrup Lufthavn for civil trafik (nu Vojens Lufthavn).

I 1967 fremsatte landsdelens konsulenter for specialundervisning ønske om, at der blev oprettet en sønderjysk observationsskole for særligt vanskeligt stillede skoleelever. Forslaget blev positivt modtaget, og ved en forhandling med amtmændene nedsattes et arbejdsudvalg, der tiltrådtes af Cai Vagn-Hansen, Peter Olesen og amtsskolekonsulent Erik Tygesen, Tønder. Samarbejdet resulterede $i$, at der blev indrettet en sådan skole $i$ en mindre ejendom i Sofiedal syd for Tinglev.

Helt siden Dronning Ingrids første ferieophold på Gråsten Slot i 1936, de første år som kronprinsesse, fattede hun interesse for det arbejde, som Sønderjydsk Hjalpefond udførte for sønderjydske børn. Dronningen deltog gennem 
årene meget aktivt $\mathrm{i}$ dette arbejde både gennem indsamlingen til Ingrid-Indsamlingen og ved de årlige tøjuddelinger, men i 1960'erne blev det klart, at behovet for den form for social støtte ikke mere var aktuelt. Spørgsmålet om Ingrid-Indsamlingens fortsatte virksomhed blev derfor drøftet på et borgmester- og amtmandsmøde i 1967, et møde, som Dronningens privatsekretær, fru Sybille Bruun, havde bedt om. Ved denne drøftelse blev man enige om at tilslutte sig Dronning Ingrids forslag, om at Ingrid-Indsamlingen fortsatte som en fond, kaldet Ingridfonden, hvis hovedopgave skulle være årligt at tildele unge sønderjyder rejselegater til udlandsrejser. De tre amtmænd og de fire borgmestre indgik som medlemmer af et rådgivende udvalg, der blev knyttet til fonden. Dette rådgivende udvalg består i dag af stiftamtmanden, amtsborgmesteren og formanden for Kommuneforeningen for Sønderjyllands Amt. Dronning Ingrid har siden hvert år personligt foretaget uddelingen af disse rejselegater. Uddelingen, der finder sted i november/december måned, har været til megen opmuntring for dygtige, unge sønderjyder.

\section{Grænseoverskridende samarbejde}

Flensburger Tage

I årene 1954, 1955, $1959 \mathrm{og}$ i en række efterfølgende år gennemførte Flensborg by nogle kulturelle arrangementer under betegnelsen Flensburger Tage. Den centrale person i disse arrangementer var byens biblioteksdirektør, Dr. Hans Peter Johannsen, der havde en enestående evne til at sammensǽxtte indholdsrige programmer, som omfattede en vifte af kulturelle indslag (musik, teater, ballet, opera, foredrag osv.).

Flensburger Tage vendte sig ikke mindst mod Nordslesvig, og her specielt til de fire købstæder. Men disse omfattende arrangementer må også ses som et initiativ, der skulle genoplive den kontakt over grænsen, som var blevet afbrudt, dels ved nazismens indtog i 1930'erne og dels ved den tyske besættelse i 1940. Men Flensburger Tage skulle også understrege Flensborgs betydning som grænselandets største bysamfund, både kulturelt og erhvervsmæssigt. Det var kendetegnende for disse arrangementer, at programmet altid omfattede både danske og tyske kunstnere og foredragsholdere. Dette forhold var medvirkende til, at arrangementerne fik stigende tilslutning nordfra.

Alligevel savnede Flensborg en stærkere respons fra Nordslesvig. Det var baggrunden for, at Dr. H.P. Johannsen i 1957 rettede skriftlig henvendelse til borgmester Jens Gjelstrup, Aabenraa, med opfordring til de fire købstæder om wat gengælde Flensborgs initiativer med lignende arrangementer i disse byer«.

Henvendelsen blev drøftet $\mathrm{i}$ et borgmestermøde i 1958, hvor det blev beslut- 
Biblioteksdirektor Hans Peter Johannsen, Flensborg var den centrale person i tilrettelaggelsen af de såkaldie Flensburger Tage fra 1954. Tegning 1978.

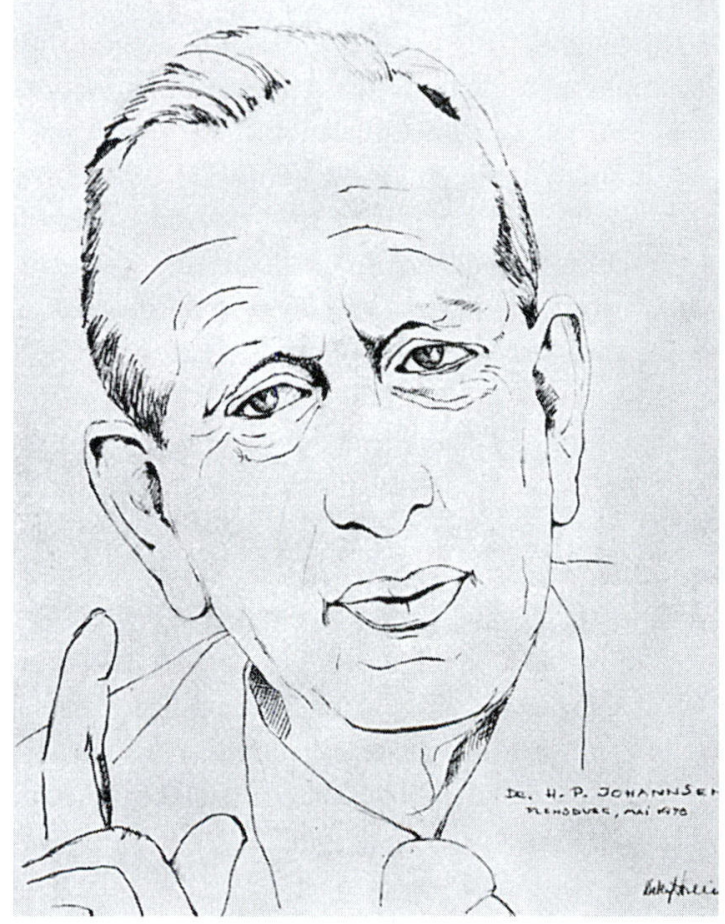

tet at drøfte sagen med professor Troels Fink, Aarhus, der få år før havde været aktivt medvirkende til gennemførelsen af de dansk-tyske mindretalsaftaler af 1955, og som iøvrigt i 1959 blev udnævnt til generalkonsul i Flensborg. Resultatet blev, at der senere samme år afholdtes et borgmestermøde på Flensborg Rådhus. Her deltog Troels Fink i en forberedende drøftelse, og efterfølgende mødtes borgmestre og kommunaldirektører med repræsentanter for Flensborg by. De afgørende samtaler fandt dog først sted over et glas vin i Gnomen Keller, hvor også Troels Fink deltog.

Flensborg var ved denne lejlighed repræsenteret af bl.a. bypræsident, Dr. Hanno Schmidt, overborgmester Thomas Andresen, borgmester Helmuth Christensen og Dr. H. P. Johannsen.

Ved denne sammenkomst var der en positiv stemning for at gennemføre arrangementer i lighed med Flensburger Tage, men nu i de fire nordslesvigske købstæder på skift med Flensborg. 


\section{De Dansk-Tyske Moder}

I fortsættelse af de drøftelser, der fandt sted i Flensborg, blev det på et senere borgmestermøde besluttet at søge gennemført et eendagsarrangement i Aabenraa. Det var dog en forudsætning, at der kunne opnås tilsagn om økonomisk støtte fra staten, evt. gennem Dansk Kultursamfund. Der blev nedsat et arrangementsudvalg, der foruden et par af borgmestrene kom til at bestå af erhvervsrådssekretær Peter Groth Bruhn, folketingsmedlem Peter Gorrsen (der også var formand for Dansk Kultursamfund) samt generalkonsul Troels Fink. Endvidere blev H.P. Johannsen, Flensborg, tilknyttet udvalget.

Resultatet af udvalgets arbejde blev, at de fire købstæder tilsluttede sig et forslag om i fællesskab at afholde et dansk-tysk møde i Aabenraa i oktober 1960. Der blev udsendt indbydelser til en lang række personer, både danske og tyske, på begge sider af grænsen, men i øvrigt var der adgang for alle interesserede. Arrangementet, der varede næsten tre dage, fandt sted i Sønderjyllandshallen, på Aabenraa Statsskole og på Grand Hotel. Hovedtalerne blev statsminister Viggo Kampmann og forbundsminister Dr. Ludwig Erhard. Planen var oprindelig, at to økonomiske ministre skulle tale, men Viggo Kampmann måtte tidligere på året forlade posten som finansminister for at afløse H.C. Hansen som statsminister. Alligevel opretholdt han sit tilsagn om at medvirke ved mødet i Aabenraa. Han var velorienteret om sønderjyske forhold, men det talte nok også med, at han her fik lejlighed til at møde Ludwig Erhard, der var arkitekten bag det tyske »Wirtschaftswunder«. Programmet omfattede desuden en række foredrag med professorerne Peter Bredsdorff, Karl Erdmann (Kiel), P. V. Glob og Svend Møller Kristensen som foredragsholdere.

To store arrangementer i Sønderjyllandshallen var med til at festliggøre dagene. Det ene var en koncert udført af Nordmark Simfonieorkester under ledelse af Generalmusikdirektor Heinrich Steiner, det andet en festaften med danske skuespillere og kunstnere.

Alt i alt blev det første Dansk-Tyske Møde en succes, også hvad deltagerantal angik. Det var det første større dansk-tyske arrangement i Nordslesvig, og det gav da også anledning til en række praktiske problemer. Eksempelvis sprogproblemet, som blev løst gennem anvendelse af et simultananlæg. Erfaringerne fra mødet viste, at man udmærket kunne klare sig med at fremlægge aftryk af talerne på begge sprog. Betragtningen var, at det var en forudsætning at fastholde sprogenes ligeberettigelse. Fordelingen af danske og tyske flag blev også gjort til genstand for en nærmere drøftelse. Det blev besluttet at anvende lige mange af hvert og placere dem skiftevis imellem hinanden. Men det vakte en vis irritation hos nogle danske Aabenraa-borgere, at der foran byens rådhus blev flaget med både et dansk og et tysk flag. Spørgsmålet om sikkerhedsforanstaltninger for Dr. Erhard blev løst af politiet i Aabenraa, uden at nogen lagde 
særligt mærke til det, bortset fra det traditionelt store opbud af motorcykelbetjente, der sikrede uhindret kørsel.

De gode erfaringer fra dette første møde førte til, at der i de følgende år - på skift med Flensburger Tage - blev gennemført en række Dansk-Tyske Møder i Nordslesvig. Møderne fandt sted i Haderslev i 1965, i Tønder i 1969 og i Sønderborg i 1973. Møderne fortsatte endnu en del gange, idet der blev gjort forsøg på at ændre deres karakter, så de blev mere folkelige, men denne udvikling blev ingen succes. Det bør erkendes, at Flensburger Tage og De DanskTyske Møder i deres koncept var arrangementer, der først og fremmest henvendte sig til ledende personer samt kommunalfolk og organisationsformænd m.fl. på begge sider af grænsen.

Indtil 1970 var det købstadborgmestrene, der tegnede møderne i Nordslesvig. Det var også især dem, der repræsenterede Nordslesvig ved arrangementerne i Flensborg. Syd for grænsen var det naturligvis især Flensborg, der skabte Flensburger Tage. I den største del af 1960'erne stod bypræsidenterne, Dr.jur. Leon Jensen og Artur Thomsen samt overborgmester Dr. Heinz Adler bag disse arrangementer stærkt støttet af dagenes utrættelige idémand, biblioteksdirektør H.P. Johannsen, der igen indgik i et fortrinligt samarbejde med kommunaldirektørerne fra de nordslesvigske købstæder.

Der er næppe tvivl om, at de dansk-tyske møder og borgmestrenes aktive deltagelse i Flensburger Tage ikke alene skabte et stort antal kontakter mellem danske og tyske på begge sider af grænsen, men at den også banede vejen for en ny dansk (og tysk) politik i det nære grænseområde. En politik, der havde til hensigt at skabe et bedre og mere positivt forhold mellem dansk og tysk. Det er kendetegnende for udviklingen i dette samarbejde, at problemerne blev færre for hvert arrangement, efterhånden som man lærte hinanden bedre at kende.

Men samtidig må det erkendes, at møderne ikke blev stedet, hvor den såkaldte »brede befolkning « mødte op. Behovet for et dansk-tysk mødested eksisterede ikke i befolkningen, hverken på den ene eller anden side af grænsen. Da møderne holdt op, havde de for så vidt løst deres opgave, nemlig: at bane vejen for en dialog og en bedre gensidig forståelse mellem dansk og tysk $i$ grænselandet. Det er her værd at erindre om, at begge mindretal deltog meget aktivt i disse arrangementer, hvad enten de fandt sted nord eller syd for grænsen.

Som nævnt fik kredsen et meget snævert samarbejde med Flensborgs biblioteksdirektør, Hans Peter Johannsen. Han var født i Tinglev og var dybt engageret $\mathrm{i}$ grænselandsforhold. Efter det Dansk-Tyske Møde i Aabenraa i 1960 gav han i en artikel i Grenzfriedensheft (nr. 4-1960) følgende beskrivelse af de fire borgmestre: »Og dermed påhviler det kronikøren på sin side at give en 


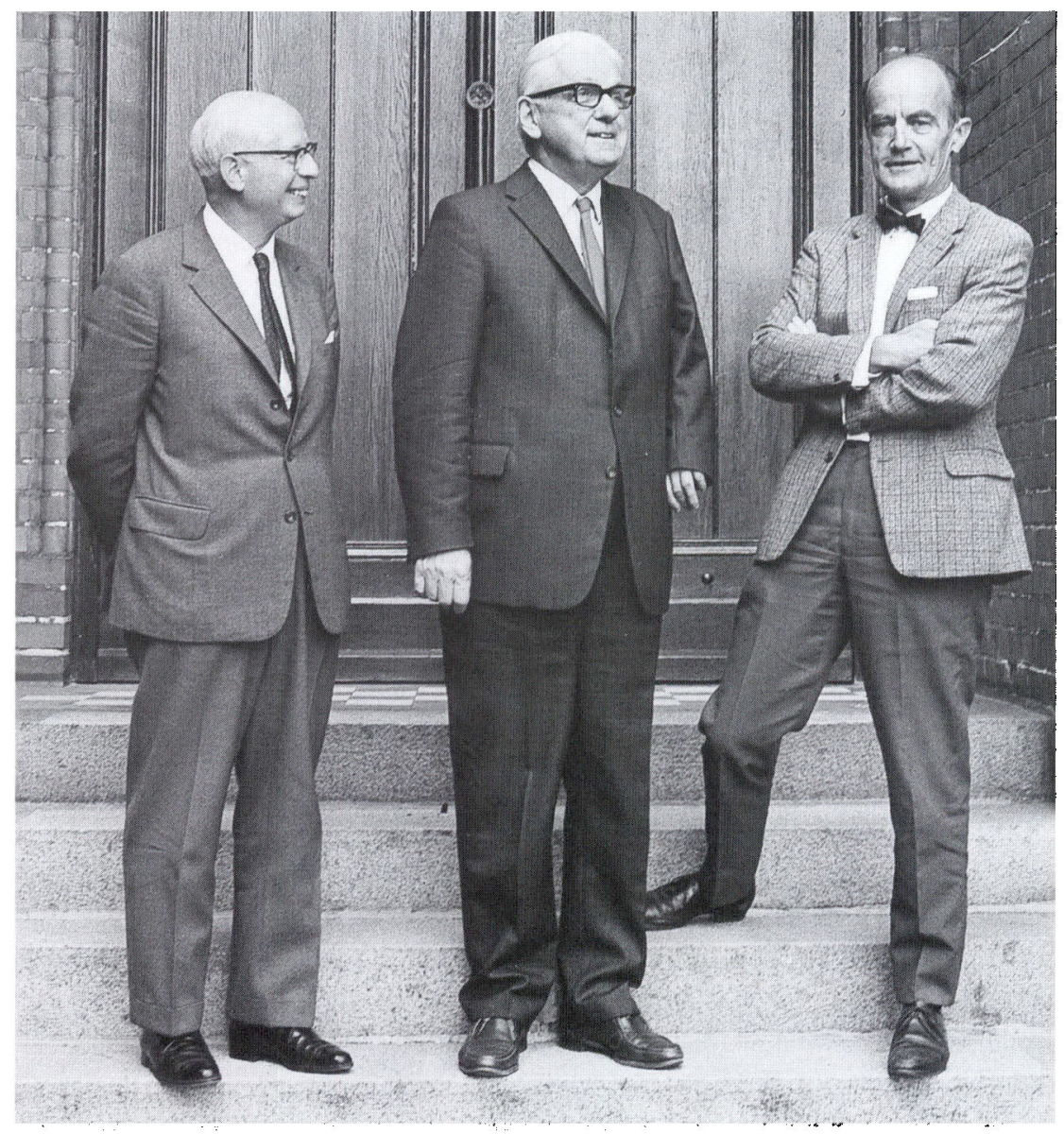

De tre amtmand, der deltog $i$ amtmands- og borgmestersamarbejdet, ses her foran hovedindgangen til amtshuset $i$ Aabenraa i efteråret 1969 efter et mode i sammenlagningsudvalget vedr. det nye sonderjyske amt. Fra venstre er det Cai Vagn-Hansen, Jens Pinholt og Tyge Haarlov. Man kan på billedet nasten se, at Tyge Haarlov havde sine helt egne meninger om den nye sonderjyske amtsinddeling.

Foto: Privateje.

kort og knap skildring af de fire borgmestre, for de var dels opfinderne og dels formgiverne ved dette betydningsfulde, kommunale arrangement. Med en lille omskrivning af en borgers bekendte udråb i Goethes Faust fristes vi til at sige om disse fire borgmestre: Vi synes godt om disse borgmestre.

Her er Johan Paulsen fra Tønder. Allerede i to årtier har han været dansk borgmester i sin by, og når det betænkes, at Tønder havde tysk borgmester længe efter afstemningen i 1920, har han lov til at føle stolthed. Han kan også 
føle sig tilfreds med, at han, der kom fra bankfaget, blev kaldet til at gøre byen delagtig i landsdelens opsving. Hans tætbyggede skikkelse, hans klare og ofte noget kølige blik lader ham fremstå som en udpræget realist. Den, der har haft fornøjelsen at lære ham nærmere at kende, ved, at han har meget høje forestillinger om en borgmesters pligter i kulturel og politisk henseende, og at han, der har dybe rødder i humanistisk tankegang, anså det for en stor opgave at optage og videreføre tanken om Flensborg-dagene; en tanke, som først og fremmest på daværende bypræsident Thomas Andresens initiativ førte til samtaler mellem lærde og politikere fra begge lande, samtaler for grænselandets interesserede forum.

Dette gav han også meget tydeligt udtryk for, da en anden borgmester, nemlig Anders Andersen fra Sønderborg, ved en første drøftelse af disse spørgsmål fremkom med nogle helt igennem berettigede betænkeligheder. Også Anders Andersen er realist i den forstand, at han forstår at tænke politisk og at omgås med et budget. Han gjorde opmærksom på, at det også nu i dag krævede særlige kundskaber og en særlig taktfølelse at virkeliggøre en sådan plan, thi ikke alle var nået så vidt som til at kunne glemme, og ikke alle var præget af den ånd, som skulle herske i en så inderligt ønsket, bedre fremtid. Andersen ville dog ikke have været Andersen, dersom han ikke allerede ud fra sit partis grundsynspunkt (han tilhører Socialdemokratiet) uden forbehold havde givet tanken sin understøttelse. I sit samarbejde viste han sig som en mand af omtanke, der kunne fatte hurtige, ofte humoristisk formulerede beslutninger, der ledsagedes af et venligt blink med øjnene.

Er Paulsen og Andersen i besiddelse af et livligt temperament, som heller ikke lader sig holde nede af deres korte piber, så fremtræder Jessen og Olesen mere afmålte. Erik Jessen, der som overhoved for den by, i hvilken mødet afholdes, må trække det største læs, udstråler en ro, som virker velgørende på omgivelserne. Han er købmand i sin fødeby og tjener den ud fra en klar erkendelse af, at denne by ligger ud til havet, og at dette i forbindelse med naboskabet sydpå i dobbelt betydning har givet den rigdom og pålagt den opgaver. I denne sammenhæng omtalte han også sin bys tyske mindretals kulturelle indretninger. For så vidt angår det personlige indtryk, bør det nævnes, at borgmester Jessen ryger cigarer.

Og nu Peter Olesen fra Haderslev. Ham var det, som i 1958 i Flensborg som talsmand for den nordslesvigske »borgmesterklub« kom med den første antydning om indbydelsen til $1960 . \mathrm{Og}$ også han har på sin meget overlagte og (hvilket skal opfattes som en kompliment) overlegne måde stillet sig i sagens tjeneste. Som Paulsen og Jessen er han også nordslesviger, han har et stort kendskab til rigdommen i dette landskab og dets mennesker, og til de mellemtoner, som man må være i stand til at kunne høre, dersom man her vil tale til 


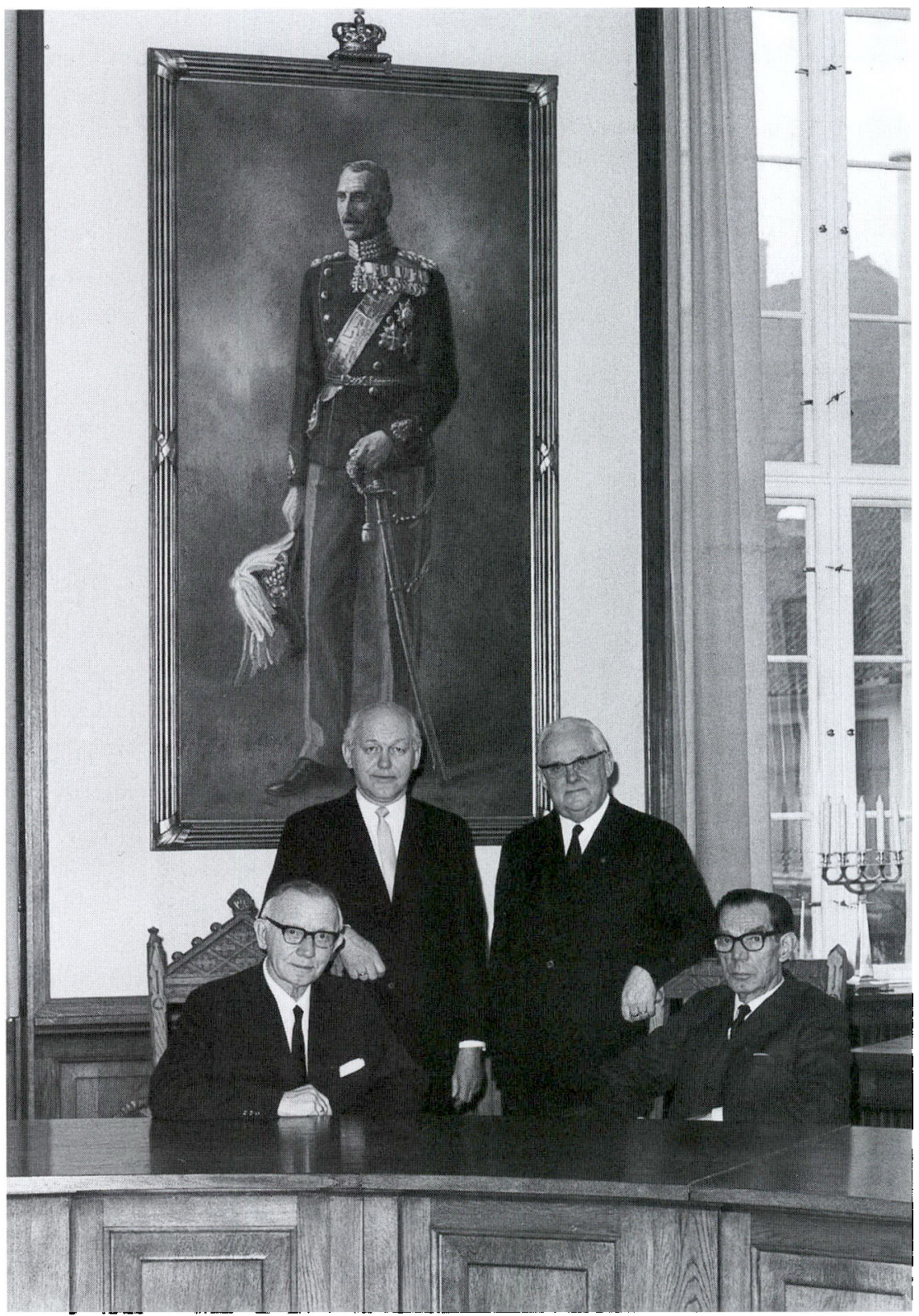

Ved et af de sidste borgmestermoder, i efieräret 1969, blev de fire borgmestre fotograferet $i$ byrådssalen i Sonderborg foran det store maleri af genforeningskongen. Christian den 10. Fra venstre Anders Andersen, Erik Jessen, Johan Paulsen og Peter Olesen. Foto: P. Clausen. Privateje. 
menneskets inderste. Tale! Han taler ikke meget - men han ser alt, hører alt og danner sig sin opfattelse og mening for så ved afslutningen af en debat at fremkomme med nogle velovervejede ord, som bliver hængende i rummet. Han elsker sin by, han elsker sin opgave, og også Aabenraamødet anså han som sin opgave."

\section{Mødernes afvikling}

Borgmestermøderne, der normalt fandt sted på skift i de fire købstæder, begyndte almindeligvis med en kop eftermiddagskaffe på det stedlige rådhus. Var der også møde med amtmændene, holdt borgmestrene et møde forud for at få afklaret de sager, der alene berørte købstæderne. Almindeligvis kunne fællesmødet med amtmændene påbegyndes et par timer senere. Til slut var der en fælles spisning, hvor maden var mindre vigtig end samtalerne. Møderne blev et nyttigt forum for udveksling af tanker og synspunkter. Her var der ingen fare for at blive citeret. Her kunne enhver tale frit, hvad man da også gjorde, idet dette forum også ofte benyttedes til at drille hinanden lidt.

I Tønder foregik spisningen altid på Hotel Tønderhus, og serveringen var altid den samme: Engelsk bøf med bløde løg og hvide kartofler. Hertil serverede borgmester Paulsen, der var stærkt interesseret i rødvinens herligheder, altid en god Bordeaux.

I Sønderborg og Aabenraa skiftedes man mellem forskellige spisesteder. I Aabenraa var det ofte GrandHotel.

Haderslev havde mere fantasi. Således inviterede Peter Olesen engang »borgmesterklubben« på sejltur gennem Haderslev Fjord i havnens nye motorbåd. Madpakkerne var medbragt, og snapseflasken hang i en snor bagud i det kølige vand. Det var dog undtagelsen, idet spisningen normalt var henlagt til Harmonien eller Hotel Norden.

Borgmestersamarbejdet, der ikke var forudset i nogen lovgivning, og for hvilket der ikke var udarbejdet nogen form for vedtægter, fik en betydelig indflydelse på udviklingen i det sønderjyske område, især i 1960'erne. Den store kommunale aktivitet $\mathrm{i}$ disse år skal bedømmes på baggrund af den udvikling, der da som helhed prægede det danske samfund. Investeringslysten var stor, de økonomiske muligheder til stede og arbejdsløsheden afskaffet.

Alt dette havde også betydning for Nordslesvig, hvor de nye og større opgaver krævede et samarbejde på tværs af amts- og købstadsgrænser - måske ikke mindst fordi der $\mathrm{i}$ landsdelen ikke fandtes et større bysamfund, som kunne fungere som et egentligt landsdelscenter.

Borgmestermøderne, der begyndte som et praktisk samarbejdsorgan, hvor 


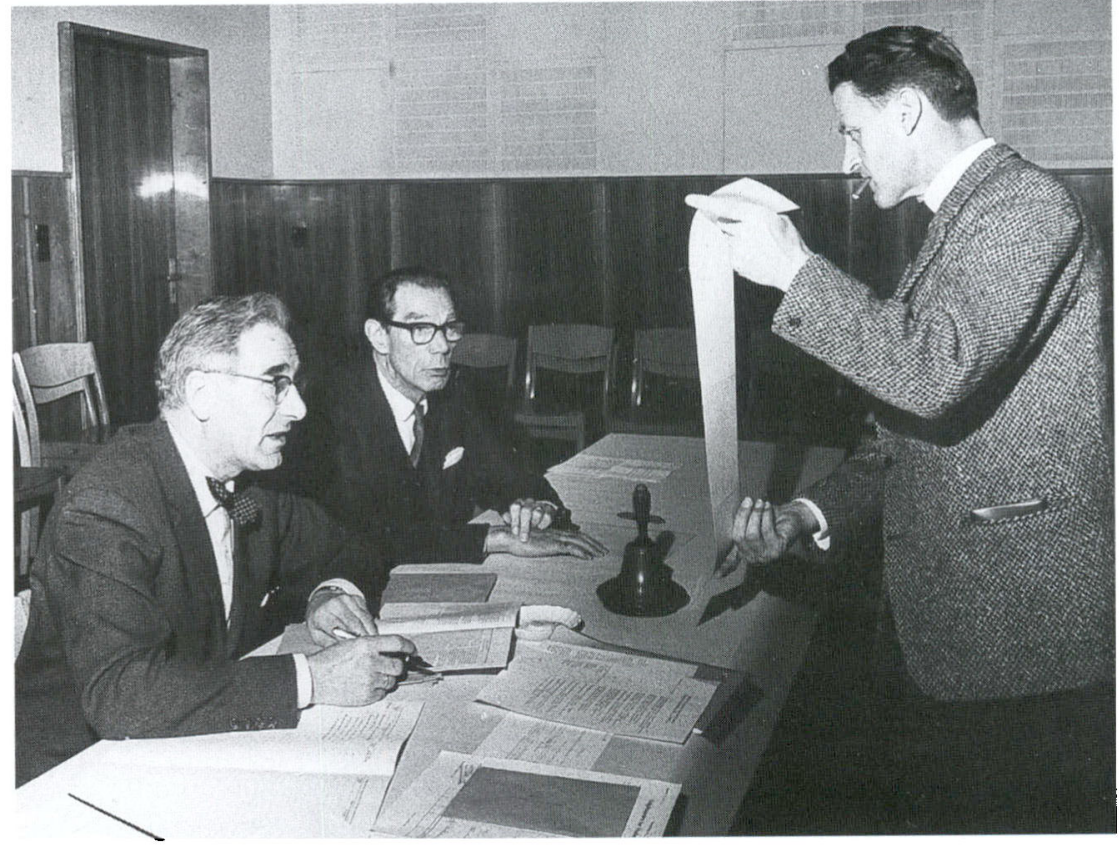

Optalling af stemmer efter folketingsvalg i Haderslev 1968. Fra venstre kommunaldirekior Tage Madsen, borgmester Peter Olesen og hyrădsmedlem Asger Sorgenfri. Foto: Hans Andersen i Institut for sonderj.sk Lokalhistorie.

man udvekslede erfaringer, udviklede sig til en institution, der fik indflydelse på mange forskellige forhold. I øvrigt et forhold, der forstærkedes, da amtmændene indgik mere fast $\mathrm{i}$ kredsen. Ikke så få vigtige aftaler og beslutninger er blevet udformet $\mathrm{i}$ denne kreds, inden de efterfølgende blev behandlet $\mathrm{i}$ de enkelte by- og amtșråd. Samarbejdet virkede som en koordinerende faktor, der igen muliggjorde en bred sønderjysk tilslutning til adskillige tiltag.

Gennemførelsen af kommunalreformen i 1970 forandrede det kommunale mønster. De hidtidige amter blev lagt sammen til et nyt stort amt, Sønderjyllands Amt, og det nye amtsråd fik en folkevalgt formand, amtsborgmesteren. Kommuner blev lagt sammen, hvorved antallet blev reduceret fra 121 til 23. Købstæderne mistede deres særlige status, idet statens tilsyn blev overført fra indenrigsministeriet til det lokale tilsynsråd.

Alt dette medførte også, at der skete nogle personskift i årene omkring 1970. Erik Jessen blev valgt som amtsborgmester, og Cai Vagn-Hansen blev statsamtmand for det nye amt. Senere blev Vagn-Hansen også stiftamtmand for Haderslev Stift. Jens Pinholt holdt op som amtmand i 1970 og som stiftamtmand i 1972, Tyge Haarløv blev - efter nogle år som regeringens sagkyndi- 


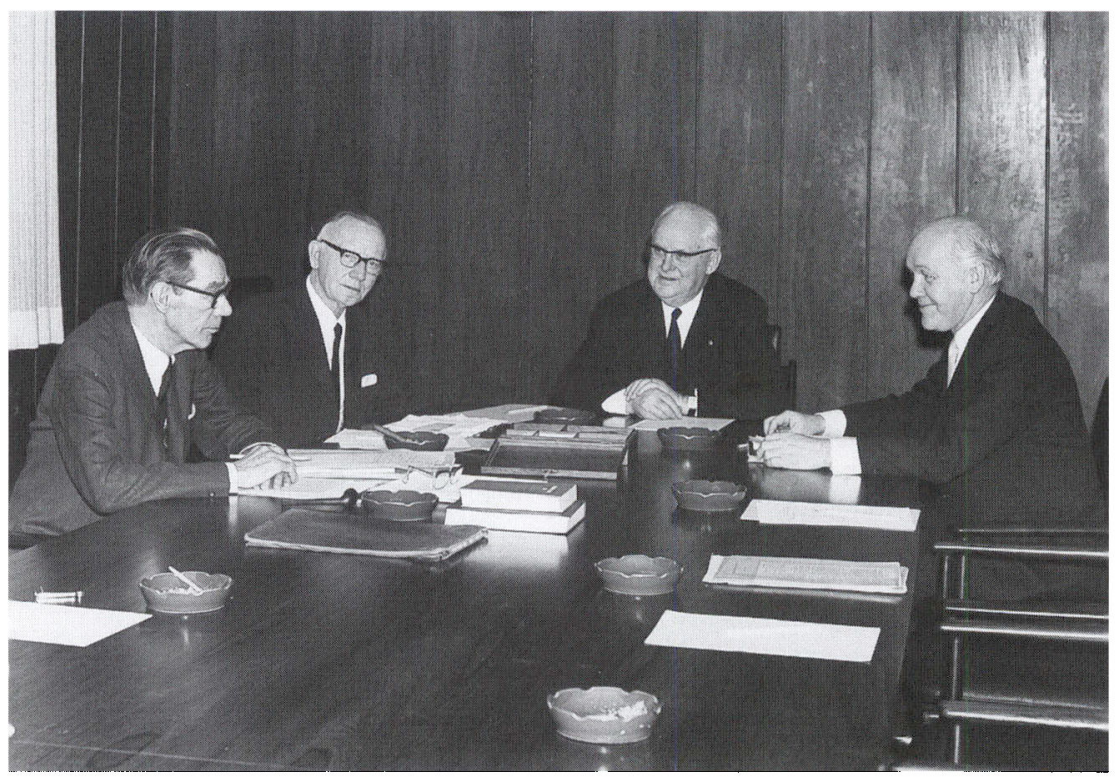

I efteråret 1969, kort for Anders Andersens dod, blev borgmestrene fotograferet ved en forhandling på Sonderborg Rådhus. Fra venstre Peter Olesen, Anders Andersen, Johan Paulsen og Erik Jessen. Billedet er typisk, idet kommunaldirektorerne altid deltog siddende placeret mellem borgmestrene. Og der er cigarer på bordet! Foto: P. Clausen. Privateje.

ge i visse EF-spørgsmål - udnævnt til stiftamtmand på Fyn. Erik Jessen fratrådte som borgmester, da han som nævnt blev valgt til amtsborgmester, og Johan Paulsen valgte at slutte sit kommunale virke. Peter Olesen blev - vel især på grund af den ret store kommunesammenlægning omkring Haderslev ikke genvalgt som borgmester. Anders Andersen døde i december 1969, få måneder før kommunalreformens gennemførelse.

Baggrunden for at fortsætte det købstadkommunale samarbejde var faldet bort, og selv om borgmestre fra de fire nye og større kommuner omkring de gamle købstæder af og til mødtes til fælles drøftelse, svandt interessen for disse sammenkomster væk, og de ophørte helt efter nogle år, dog blev der i fællesskab gennemført nogle Dansk-Tyske Møder. 
NOTE 1

Nordslesvigske kobstadsborgmestre 1920-70:

Haderslev

1920 (fra februar til maj)

Redaktør Nicolai Svendsen (1873-1965)

Den danske gruppe

1920-22 Bagermester Thorvald Møller (1858-1923)

Den danske gruppe

1922-29 Direktør Laurentius Christensen (1855-1929)

Den danske frellesliste

1929-45 Landsretssagfører Andreas Thulstrup (1897-1955)

Venstre

1946-54 Amtsforvalter Orla Christensen (1895-1984)

Det Konservative Folkeparti

1954-70 Stiftsbogholder Peter Olesen (1900-1983)

Socialdemokratiet

Sonderborg

1920-22 Manufakturhandler I. H. Koch (1874-1964)

Borgerliste

1922-33 Lærer Johann Jacobsen (1864-1937)

Socialdemokratiet

1933-46 Bankdirektør Hans Nielsen (1881-1950)

Venstre

1946-69 Maskinarbejder Anders Andersen (1901-1969)

Socialdemokratiet

1969-70 Skoleinspektør Karl Th. Jensen (1899-1983)

Socialdemokratiet

Tonder

1920-25 Sparekassedirektør Oluf P.Olufsen (1869-1937)

Tysk

1925-37 Købmand Johannes Thomsen (1881-1941)

Tysk

1937-39 Landsretssagfører Holger Jepsen (1894-1973)

Det Konservative Folkeparti

1939-70 Bankdirektør Johan Paulsen (1901-1981)

Det Konservative Folkeparti

Aabenraa

1920-46 Købmand Holger Fink (1879-1959)

Venstre

1946-50 Rektor Georg Buchreitz (1905-85)

1950-58 Direktør Jens Gjelstrup (1893-1981)

1958-70 Købmand Erik Jessen (f. 1919)

Dansk liste uden for partierne 
NOTE 2

Administrationschefer $i$ de nordslesvigske kobstader 1920-1970:

Haderslev

1921-61 Byrådssekretær og kontorchef, fra 1934: Kommunaldirektør Edmund Melander (18911976)

1961-83 Kommunaldirektør Tage Madsen (f. 1917)

Senderborg

1920-38 De administrative ledere kan ikke nærmere specificeres. To navne er dog nævnt. Kæmner A. Boysen og kontorchef Jakob Christensen.

1938-70 Kæmner Georg Kæstel (1903-1979)

Tonder

1920-33 Byrådssekretær Jørgen Thorsen (1884-1956)

1933-45 Kæmner Jens Johannsen Schmidt (1896-1960)

1945-76 Kontorchef og fra 1963 kommunaldirektør Ludvig Nielsen (1910-1991)

Aabenraa

1920-26 Byrådssekretær Christian Iwersen (1892-1964)

1926-62 Byrådssekretær og kontorchef, fra 1946:

Kommunaldirektør Jørgen Christensen (1895-1980)

1962-83 Kommunaldirektør Erik Haugbølle (f. 1920)

NOTE 3

Amtmand og stiftamtmand 1920-1970:

Haderslev amt

1920-31 Cand.jur. Viggo Rothe Haarløv (1872-1931)

1931-44 Cand.jur. Christian L. Lundbye (1873-1947)

1944-70 Cand. jur. Jens Pinholt (1902-1990)

Sonderborg amt

1920-31 Cand.jur. Christian L. Lundbye (1873-1947)

1931-54 Cand.polit. Kresten Refslund Thomsen (1884-1960)

1954-70 Cand.jur. Cai Vagn-Hansen (1911-1990)

Tonder Amt

1920-49 Otto Didrik Lensgreve Schack (1882-1949)

1949-60 Cand.jur. Mogens J. Clausen (1908-1987)

1960-70 Dr.jur. Tyge Haarløv (1919-1989)

Aabenraa amt

1920-54 Cand. polit. Kresten Refslund Thomsen (1884-1960)

1954-70 Cand. jur. Cai Vagn-Hansen (1911-1990)

Efter stiftamtmand Viggo Haarløv's død i 1931 blev de statslige administrationer i Sønderborg og Aabenraa sammenlagt til én administration, placeret i Aabenraa. Der opretholdtes dog to amtskommunale administrationer og to amtsråd, men med fælles formand, nemlig amtmanden over Aabenraa 
og Sønderborg amter. Ved samme lejlighed flyttede Christian Lundbye fra Sønderborg til Haderslev og Kresten Refslund Thomsen overtog ledelsen af det nye Aabenraa-Sønderborg Amt, hvor han i 1954 afløstes af Cai Vagn-Hansen, der i 1970 udnævntes til amtmand over Sønderjyllands Amt og i 1972 også til stiftamtmand over Haderslev Stift.

\section{KILDER}

Forhandlingsprotokol for møder mellem sønderjydske købstadsborgmestre 1950-1970. Tønder Kommunes arkiv. Landsarkivet Aabenraa.

Enkelte sagsmapper fra Aabenraas Kommunes arkiv. Landsarkivet Aabenraa.

Vagn Harsberg: De sønderjyske amtsråd indtil 1970. Sønderjyllands amtsråd 1984.

Sønderjyllands Erhvervsråd 1951-1976. Sønderjyllands Erhvervsråd.

Beretning fra udvalget vedrørende Sønderjyllands Udviklingsprogram 1968.

Hans Peter Johannsen: Sieben schleswigsche Jahrzehnte. Schleswiger Druck- und Verlagshaus, Schleswig 1978.

Jes Peter Caspersen: Sådan var det. Erindringsbilleder. Historisk Samfund for Sønderjylland. 1990 Vores egne vindver. Udvalgte artikler fra tidsskriftet Grenzfriedenshefte, udgivet af Studieafdelingen, Flensborg. Forlaget Skandia 1967. 